\title{
The Significance and Manifestations of Youth Value Orientations in the Structure of Social Competence
}

\author{
Tatiana Merdeeva \\ Sholom-Aleichem Priamursky \\ State University \\ Birobidzhan, Russia \\ tmerdeeva@rambler.ru
}

\author{
Natalia Bazhenova \\ Sholom-Aleichem Priamursky \\ State University \\ Birobidzhan, Russia \\ n-bazhenova@yandex.ru
}

\begin{abstract}
To study the significance and manifestations of youth value orientations in the structure of social competence and determine their influence on behavior in a situation of social threat or danger, a diagnosis of value orientations of youth (students of Birobidzhan Medical College, Birobidzhan College of Culture and Arts) by M. Rokich was carried out. The research also included the analysis of questionnaires of students to identify their sensitivities to social threats and dangers. The study showed that among the terminal youth values health, love, presence of good and faithful friends turn out to be the most important ones. Among the instrumental values accuracy, upbringing, education, responsibility and cheerfulness are ranked first. These fundamental students' values are a part of the structure of social competence of modern youth, which influence their behavior in a situation of social threat or danger. By performing the regulatory function of behavior, value orientations allow students to behave properly and to avoid the situation of social danger or threat.
\end{abstract}

Keywords - value orientations, social competence, youth, social threats and dangers.

\section{INTRODUCTION}

Socio-cultural transformations taking place in the society determine the reasons for researchers to study the phenomenon of social competence.

Globalization processes not only offer great opportunities for personal development and self-realization, but also raise serious concerns. They are often the cause of social instability, lead to the emergence of social threats and dangers in the society, and can cause destructive behavior of the individual. This problem is particularly acute when it comes to youth. Psycho-physical features and conditions of socialization of youth can provoke in their environment the spread of drug addiction, extremism, dependence on social networks etc.

The structural components of social competence, united in some integrity, give the right to consider it as a tool to confront social threats and dangers. A special role in this complex mechanism is given to values and value orientations.
The term "orientation" can be considered as a process that imply actions carried out to achieve the desired result, the choice of the goal and means of achievement as well as the evaluation of actions. The process of awareness of values by the individual involves the presence of orientation technique in any form or a group of values.

Orientation technique is the internal mechanism that generates preferences of the individual, the nature and focus of which define peculiarities of his valuable relationship to material or spiritual things, considered as objects, goals, and tools. Value orientations serve as criteria for personal assessment and choice which can be moral or immoral, good or bad, important or not.

The study of value orientations was carried out by famous classics of sociology E. Durkheim [1], N. Smelzer [2], T. Parsons [3], [4], [5], P. Sorokin [6], etc.

According to E. Durkheim, values become the stimuli of human behavior.

N. Smelser treats them as beliefs about the goals and tools used to achieve them by people.

T. Parsons "'voluntaristic theory of social action" is based on the fact that it is not the society that sets the vector of human behavior, but values and norms, learned by the individual which affect his behavior. Being in the position of choice, the individual makes an independent decision in a particular situation and acts "independently", under the guidance of its own value orientations.

This position can be easily explained. Value orientations are an integral system that includes cognitive, emotive, and behavioral components. Changes in knowledge, beliefs, ideals, significance of human life, feelings and emotional assessments cause personal changes and affect social behavior. The development of personality and the ability to resist social threats and dangers depend on what value orientations will be dominant and system-forming.

The study of youth value orientations was carried out by S. V. Iavon [7]; A. Baishukurova, K. Bassybekova [8]; D. M. Rusakova [9]; E. Skimina, J. Cieciuch, Sh. H. Schwartz, E. Davidov, R. Algesheimer [10]. 
Ramilya Sh. Kasimova, Gulnara F. Biktagirova [11] investigated the phenomenon of social competence; Linda Rose-Krasnor [12].

Malin Brännback, Shahrokh Nikou, Harry Bouwman [13] studied models (structures) of social competence.

G. A. Corredor [14], A. Justicia-Arráez, M. RomeroLópez, A. Benavides-Nieto [14] pointed out the influence of social competence on the behavior of the individual.

S. J. Stroessner, A. A. Scholer, D. M. Marx, B. M. Weisz [15], discussed peculiarities of the perception of threats and dangers.

N. Chetty, S. Alathur [16] pointed out negative effects of social networking sites as one of the types of global threats to people.

G. U. Soldatova, E.I. Rasskazova [17] carried out a research of the relationship of youth digital competence and their behavior when using social networks and the Internet.

Youth, mastering social values expressed in social ideals, norms, goals, orientations, accumulate social and cultural experience that contributes to the development of personal value orientations being important for young people. This happens in the process of youth socialization.

The development and reproduction of previously formed social values by youth contributes to the preservation of stability in the society. Otherwise, the gap between the traditional values of society and youth values can cause disorientation and demoralization of the younger generation, increase the risk of falling under the negative influence of threats and social dangers leading to social destruction.

As one of the structural components of social competence, value orientations serve as a link between the desired and actual behavior of youth. In this case, their function in the structure of social competence can be compared by analogy with DNA molecules. In human DNA, each base on one of the circuits is associated with one specific base on the second circuit on the principle of complementarity, i.e. the information contained in one DNA chain is contained in the other as well.

The same happens with social behavior of a person in a particular situation in the event of a social threat or danger because the values ensure the coincidence of the desired and real behavior.

Inconsistency in value orientations, on the contrary, causes inconsistent and unpredictable human behavior and, most likely, social destruction.

The aim of the work is to study the significance and manifestations of youth value orientations in the structure of social competence, as well as to determine their influence on the behavior of students in different situations of social threat or danger.

\section{METHODS}

The definition of significance and manifestations of youth value orientations in the structure of social competence was carried out in two stages.

The first stage included a sociological survey to determine students' value preferences.
The second stage of the research was to identify the significance of the value component in the structure of social competence to determine the peculiarities of behavior in situations of social danger or threat.

Randomly selected respondents aged 15 to 22 (mean age 16-19 years old) enrolled on the 1-2 courses of Birobidzhan Medical College, Birobidzhan College of Culture and Arts (18 boys and 62 girls) were used in the survey. The specifics of educational institutions to conduct the survey explains the prevalence of the number of female respondents in the experiment. To find out sensitivities to social threats and dangers and understand their mode of behavior we used the method of value orientations of $M$. Rokich and a questionnaire especially developed for this purpose.

\section{RESUlts AND DisCUSSION}

The first stage of the study consisted in determining the youth value orientations, namely their value preferences. According to M. Rokich (1973), values represent stable beliefs about preferred ways of behaving. The first type is terminal values, which represent the preferred ultimate goals of existence. These values, in a way, determine what a person aspires to, his or her life significance. For a more accurate understanding of the meaning of the values, it is possible to ask specifying questions "What for?" and "Why?"

The analysis of the results of the group hierarchy of value orientations of $\mathrm{M}$. Rokich [18] revealed the average value rank of each of the values (Fig. 1):

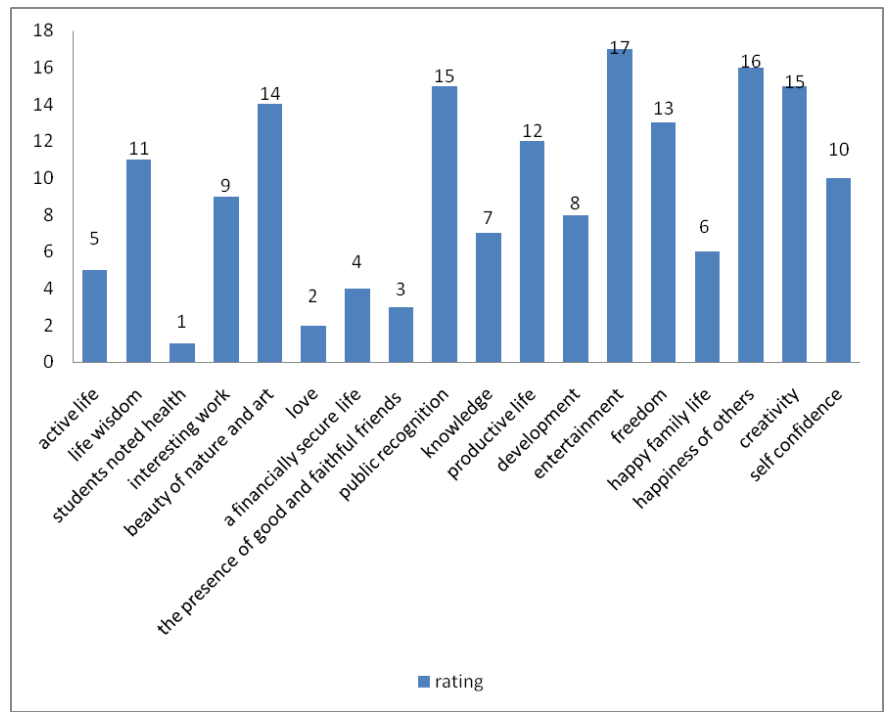

Fig. 1 - The average value rank of terminal values

In the list of significant terminal values, students noted:

- health (physical and mental) $-32.5 \%$ (26 people);

- love (spiritual and physical intimacy with a loved person) $-13.75 \%$ (11 people);

- the presence of good and faithful friends $10 \%(8$ people). 
Terminal values are more sustainable. According to the ratings of life values, based on the study of youth in different regions, health is included into the top three most important values. Modern youth of other regions also include such terminal values as "love" and "the presence of good and faithful friends." The results of our study coincide with the previous results. At the end of the last century, these values had an average rating. On the contrary, the dominant value of the "happiness of others" in the 1970s and 1980s today is one of the least significant. According to the results of the survey, it occupies the 16 th position.

Instrumental values directly explain human behavior. These are the values that guide the individual in a given situation: responsibility/ irresponsibility, honesty/ dishonesty, etc.

According to the results of the survey (Fig. 2.):

- accuracy (cleanliness) and the ability to keep things in order, occupy the first place in the list of significant instrumental values of the respondents; order in business - 17 people (21.3\%);

- education (good manners) - 20 people (25\%);

- education (breadth of knowledge, high General culture) -12 people $(15 \%)$

- followed by responsibility (sense of duty, the ability to keep one's word) -14 people (17\%);

- cheerfulness (sense of humor) - 20 people (25\%).

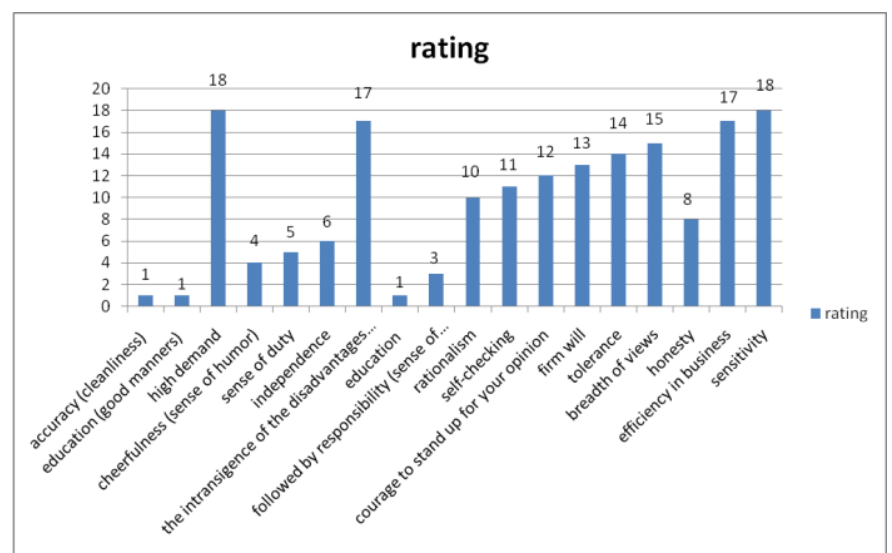

Fig. 2 Average values rank of instrumental values

Instrumental values such as "high demands" (this fact is very interesting because it contradicts clearly observed trends and requires additional analysis) and "intransigence to shortcomings in oneself and others" were paramount for adolescents in the past decades, and now occupy one of the last places. Breadth of views, efficiency in business, sensitivity (care) take the latter positions.

Further research was to identify the work of the value component in the structure of social competence. We used five true to life situations that could actually happen to the respondents to determine their peculiarities of behavior.
In each situation, which was based on the ability to behave in the risk of a social danger or threat, students were asked to explain their behavior.

Situation 1: "You go down the street and suddenly you see a fight of two unknown drunk men. What will your actions be?" - The following responses were received:

- I will pass by -53 people ( $66 \%$ );

- Call the police -16 people (20\%);

- Call for help - 8 people (10\%);

- Begin to separate - 2 people (3\%);

- Tell them to stop fighting - 1 person (1\%).

The predominance of respondents' answers" Pass by" and "Call the police" can be explained by the fact that for the majority of subjects the main values are health (terminal values) and responsibility (sense of duty, ability to keep one's word) (instrumental values). Respondents chose such answers from the point of view of their own safety and health.

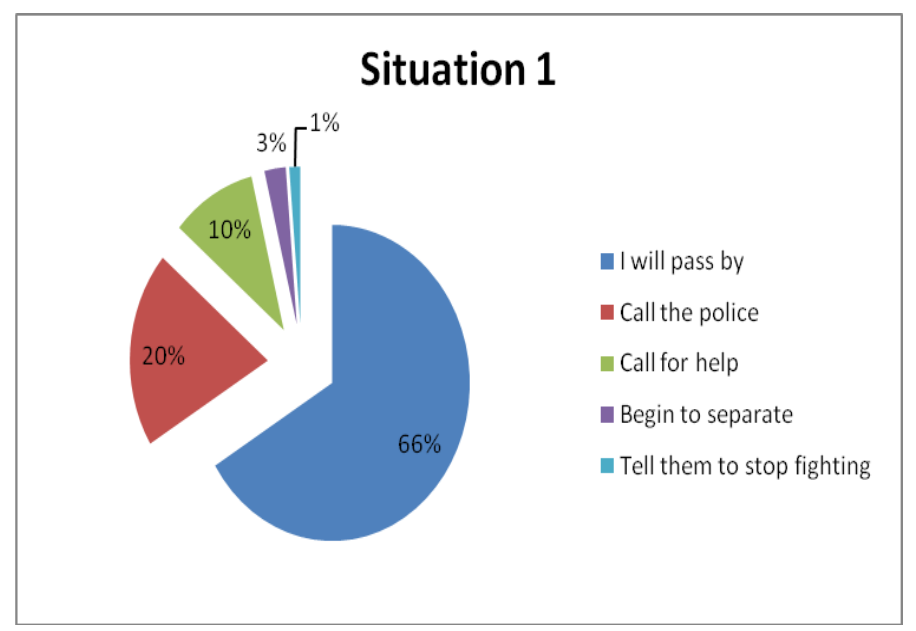

Fig. 3 Distribution of responses in Situation 1

Situation 2: "Your friend borrowed a book and promised to return it in a week. A month passed since then, and the book has not been returned. You need it badly to prepare your homework. Yesterday, you called his house and reminded him of the book, and he vowed to bring it. However, today he says, "I'm Sorry, I forgot where I had put it, and now I can't find it." What are you going to do?"

The respondents' gave the following answers:

- I will tell him to return the book - 33 people (46\%);

- I will forget the whole thing - 17 people (24\%);

- I will go to his place to try to get the book - 13 people $(7 \%)$;

- I will yell at him - 11people (15\%);

- I will get offended and will not give him books anymore - 6 people (8\%). 


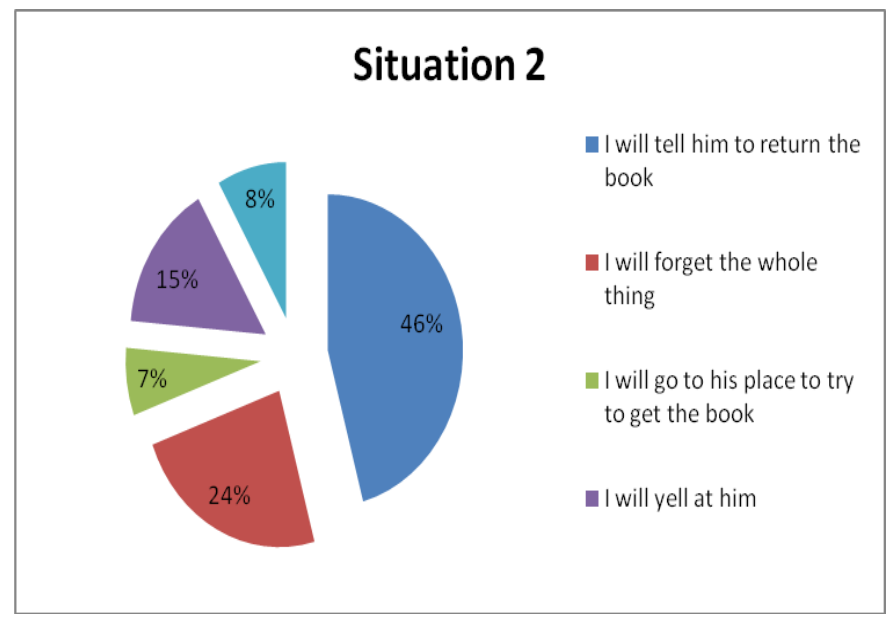

Fig. 4 Distribution of responses in Situation 2

Among the instrumental values, the respondents gave preference to education. Good manners are the basis of the behavior of a well-educated person in the society. Their components are human modesty, restraint, the ability to control their actions, attentive and tactful communication with people. Respondents chose the most optimal mode of behavior in this situation, which does not imply any negative consequences that can lead to a conflict, choosing the option "I will tell him to return the book." In addition, the choice of such behavior is determined by the value of having good and faithful friends.

Situation 3: "You are travelling by the train and suddenly see a man standing up and getting off the train at the next stop leaving a small package. Judging by the man's behavior, you understand that he forgot the package for a reason. What will your actions be?"

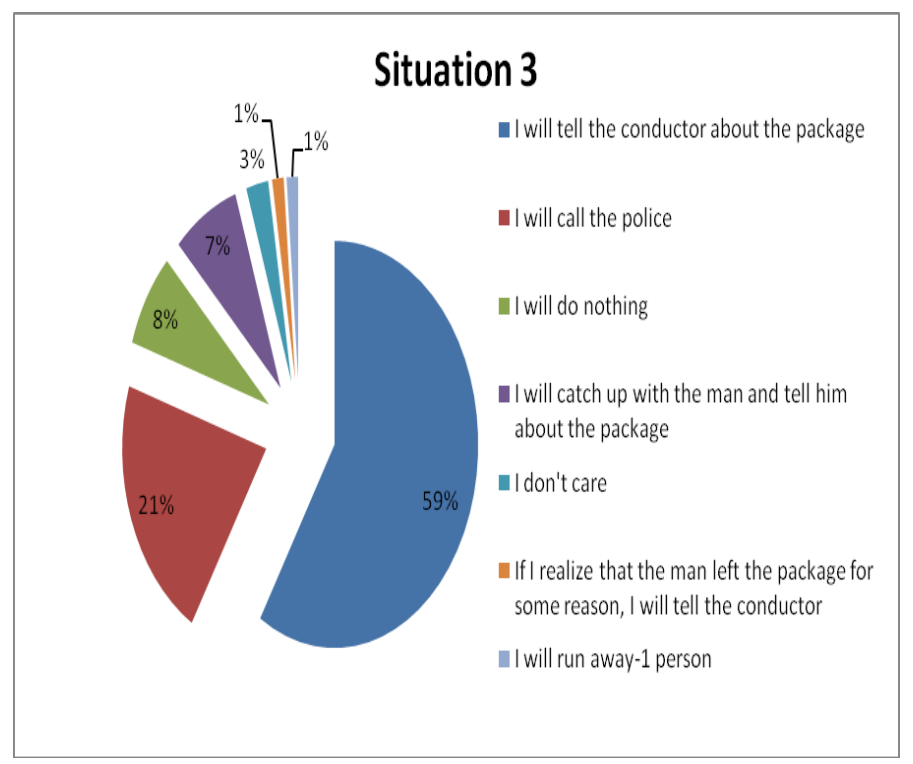

Fig. 5 - Distribution of responses in Situation 3

The respondents' answers:

- I will tell the conductor about the package - 47 people (59\%);
- I will call the police - 17 people (21\%);

- I will do nothing - 6 people (8\%);

- I will catch up with the man and tell him about the package - 6 people (7\%);

- I don't care - 2 people (3\%);

- If I realize that the man left the package for some reason, I will tell the conductor - 1 person (1\%);

- I will run away-1 person (1\%).

The frequency of responses to "tell the conductor about the package" and "Call the police" is also due to the predominance of health values (physical and mental) and responsibility.

Responsibility coincides with the concept of personal and public duty. The ability to take responsibility is the main quality of a mature person and a socially competent person.

The presence of internal control together with a rather developed reflexive position and the desire for self-analysis will be the criteria for the formation of responsibility. The assessment of this situation allows the Respondent to feel the emergence of a potential threat of a terrorist act. Responsible behavior and the fear to jeopardize his health forced him to act consciously without putting himself and other people at risk.

Situation 4: "Your group is going away for the May holidays to another city for a few days. You arrive in the evening when there are no excursions planned for that day. The hotel, where you are going to stay, is not located in one building, and includes many small houses accommodating up to 10-15 people each at a time. Your classmates and you find yourselves in one building, and but your teachers are staying in another one. One of your classmates suggests going for a walk around the city at night, because, as he says, no one is going to check them there at that time, and he reassures you that they will return in the morning. Almost everybody agrees, except 2-3 children, who never participate in such like antics. Will you support the idea or stay at the hotel? Explain your point of view".

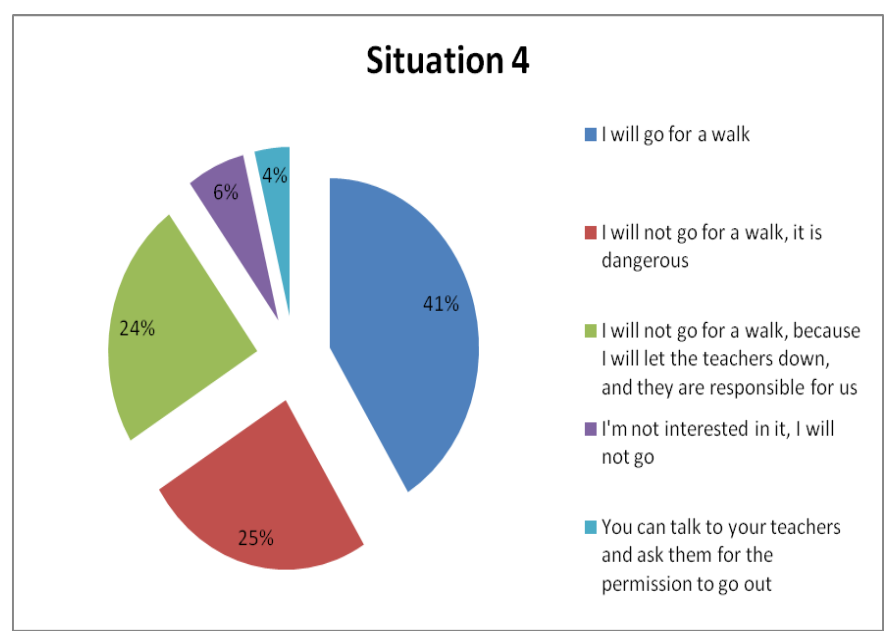

Fig. 6 - Distribution of responses in Situation 4 
The respondents' answers:

- I will go for a walk - 33 people (41\%);

- I will not go for a walk, it is dangerous - 20 people $(25 \%)$

- I will not go for a walk, because I will let the teachers down, and they are responsible for us - 19 people $(24 \%)$;

- I'm not interested in it, I will not go - 5 people (6\%);

- You can talk to your teachers and ask them for the permission to go out -3 people (4\%).

In this situation, the maximum number of answers is determined by "I will not go for a walk, it is dangerous", "I will not go for a walk, because the teachers are responsible for us" - 39 people chose such answers, which is also due to the significant values of health and responsibility. However, you can see that 33 people chose the option of "going for a walk". Cheerfulness, as well as the presence of good and faithful friends are also among the important values and it explains the students' choice.

Cheerfulness helps to get rid of sadness, indifference, depression, and, most often does not depend on the current state of affairs. This value makes students optimistic about things and not think about the consequences in the future. Since the social competence of the individual is a complex integrative structure, the components of which are in close interaction with each other, it is necessary to have welldeveloped cognitive (knowledge) and reflexive components to choose the correct modes of behavior in this situation.

These components will make other values such as health and responsibility work, and despite the optimistic attitude to life, students will still be able to think about the consequences and assess the situation correctly.

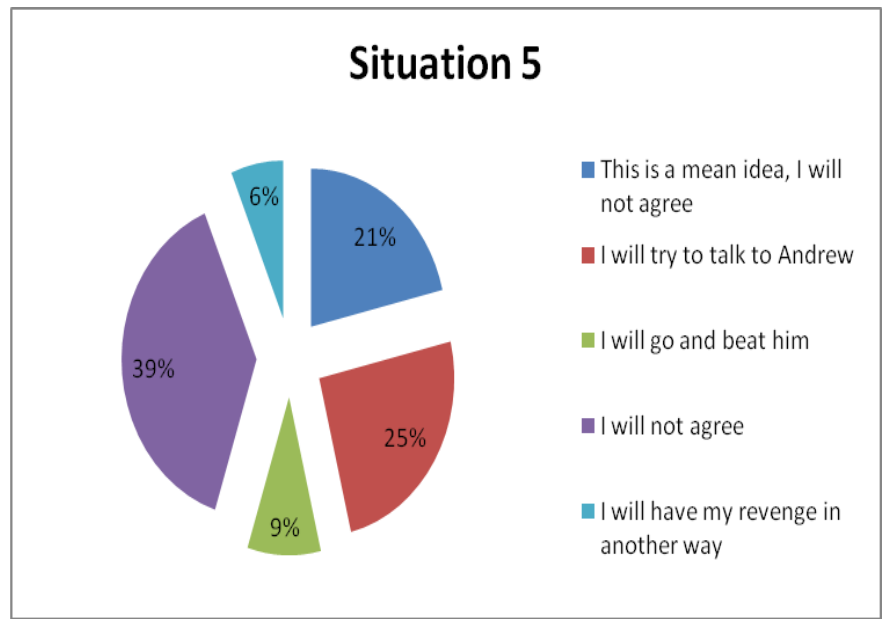

Fig. 7 - Distribution of responses in Situation 7

Situation 5: "You are in school. There is a boy named Andrew in your class who behaves too arrogantly and sometimes allows himself to taunt you. Once your friend Alex offers you to take your revenge on Andrey, and watch him on the way home and beat him a little. What will your actions be? Will you agree? Explain your decision."

The respondents' answers:

- This is a mean idea, I will not agree - 17 people (21\%);

- I will try to talk to Andrew - 20 people (25\%);

- I will go and beat him - 7 people (9\%);

- I will not agree - 31 people (39\%);

- I will have my revenge in another way - 5 people (6\%).

In this situation, upbringing, education, knowledge and responsibility influence the students' behavior directly, performing the function of restraining mechanism.

\section{CONCLUSION}

To sum up, one of the structural components of social competence of the individual is the value component.

Personality value orientations have different effects on behavioral aspects, but it is quite possible to say that, choosing the mode of behavior or the way of acting in a situation of social danger or threat, a person will rely on his own system of value orientations.

The analysis of respondents' answers confirmed the following theses:

- value orientations are an essential element of personality consciousness, the formation of which takes place in the process of socialization;

- the value component is directly related to the behavioral component in the structure of social competence of youth;

- the meaning and importance of value orientations in the structure of social competence of youth influence their behavior directly and perform regulatory functions of behavior in situations of social threat or danger;

- the hierarchy of value orientations according to the degree of their importance for students shows that they assimilate social norms by introducing the category of "badgood" into interpersonal relationships and showing independence while losing unconditional orientation towards an adult.

Learning to distinguish his opinion from the opinions of other people, the student understands that his behavior affects the solutions of many life situations, including difficult from the point of view of social interaction, which mean that he is ready to master the skills of constructive behavior, including situations of social danger.

\section{REFERENCES}

[1] E. Dyurkgeym, "Tsennostnyye i real'nyye suzhdeniya", Sotsiologicheskiye issledovaniya, vol. 2, 2001, pp. 46-54.

[2] N. Smelzer, Sotsiologiya: per. s angl. Moscow: Feniks, 1994, pp. 688.

[3] T. Parsons, Sistema sovremennykh obshchestv, Moscow: Aspekt-Perss, 1998.

[4] T. Parsons, Social systems and the evolution of action theory. General psychology basics. SPb.: Piter, 1977. 
[5] T. Parsons, O strukture sotsial'nogo deystviya / T. Parsons. - 2-ye izd. M. : Akademicheskiy Proyekt, 2000, p. 880.

[6] P. A. Sorokin, Krizis nashego vremeni Chelovek. Tsivilizatsiya. Obshchestvo / obshch. red., sost. i predisl. A.YU. Sogomonov: per. s angl. - M., 1992, pp. 429.

[7] S. V. Iavon, " The Value Orientations of Young People in the Middle Volga Region,” Russian Education And Society, vol. 55(7), pp. 14-26, July 2013.

[8] A. Baishukurova, K. Bassybekova, "The problem of value orientations of the modern youth," International journal of psychology, vol. 51, pp.1075-1075, July 2016.

[9] D.M. Rusakova, "Valuable orientations of modern youth. World of Science," Series: Sociology, Philology, Cultural Studies, [online], vol. 1(9), 2018. Available at: https://sfk-mn.ru/PDF/06SCSK118.pdf (in Russian).

[10] E. Skimina, J. Cieciuch, S. Schwartz, E. Davidov, R. Algesheimer, "Testing the circular structure and importance hierarchy of value states in real-time behaviors", Journal of Research in Personality, vol. 74, pp. 42-49, 2018.

[11] R. Sh. Kasimova, G. F. Biktagirova, "Formation of Adolescent Social Competence", Helix, vol. 8(1): 2017, pp. 2560- 2567.

[12] L. Rose Krasnor, "The Nature of Social Competence: A Theoretical Review," Social Development, vol. 6(1), pp. 111-135, 2006.
[13] M. Brännback, Sh. Nikou, H. Bouwman, "Value systems and intentions to interact in social media: The digital natives," Telematics and Informatics, vol. 34(4), pp. 365-381, July 2017.

[14] G. A. Corredor, A. Justicia-Arráez, M. Romero-López, A. BenavidesNieto, "Longitudinal Study of the Effects of Social Competence on Behavioral Problems," Procedia - Social and Behavioral Sciences, vol. 237 (2017), pp. 479-485.

[15] S. J. Stroessner, A. A. Scholer, D. M. Marx, B. M. Weisz, "When threat matters: Self-regulation, threat salience, and stereotyping," Journal of Experimental Social Psychology, vol. 59, pp. 77-89, 2015.

[16] N. Chetty, S. Alathur, "Hate speech review in the context of online social networks," Aggression and Violent Behavior, vol. 40, pp. 108118, May 2018.

[17] G. U. Soldatova, E. I. Rasskazova, "The 〈<dark side〉> of digital competence of Russian adolescents: illusion of competence and risky behavior online," Voprosy Psikhologii, vol. 3, 2017.

[18] M. Rokich, Priroda chelovecheskikh tsennostey. Moscow, 1973, pp. 243. 